\title{
TINJAUAN YURIDIS TINDAK PIDANA DALAM KEMERDEKAAN MENYAMPAIKAN PENDAPAT DI MUKA UMUM MENURUT UNDANG-UNDANG NO.9 TAHUN 1998
}

\author{
Oleh \\ Joejoen Tjahjani \\ Dosen Fakultas Hukum Universitas Islam Lamongan
}

\begin{abstract}
ABSTRAK
Tujuan saya meneliti ini untuk mengetahui apakah kebebasan berekspresi dan menyampaikan pendapat di muka umum dapat dikategorikan tindak pidana, mengetahui kriteria kebebasan berekepresi dan menyampaikan pendapat dimuka umum dapat dikategorikan sebagai tindak pidana. Dan metode penelitian yang saya gunakan adalah yuridis normative dengan bahan hukum yang saya gunakan adalah data sekunder dengan cara studi kepustakaan dan data yang mengarah pada kajian-kajian yang bersifat teoritis menghasilkan kesimpulan sebagai berikut: Berdasarkan pembahasan yang telah saya uraikan pada bab sebelumnya maka terhadap permasalahan yang ada dapat ditarik kesimpulan kebebasan berekspresi dan menyampaikan pendapat dimuka umum; Demonstrasi, Unjuk rasa, mimbar bebas, rapat terbuka, pawai dan bentuk protes lainnya adalah hak asasi manusia yang dijamin oleh Piagam Hak-hak asasi Dunia dan UUD 1945, tetapi pelaksanaanya harus dilakukan secara bertanggung jawab dengan menjunjung tinggi nilai - nilai agama, kesusilaan dan tunduk pada ketentuan perundangan-undangan yang berlaku, agar tidak mengganggu hak dan kebebasan orang lain serta kepentingan masyarakat
\end{abstract}

\section{Kata kunci: Tinjauan, Yuridis, Tindak pidana, Kemerdekaan}

\section{PENDAHULUAN}

Perjuangan untuk membela persamaan hak, kebebasan berfikir, berkeyakinan, beragama, berserikat dan berkumpul serta hidup merdeka tanpa paksaan telah berlangsung sejak awal peradaban manusia di bumi.

Dalam perjuangan untuk membela persamaan, kebebasan berfikir, berkeyakinan, beragama, berserikat dan berkumpul sebagai hak dasar manusia, yang lebih di kenal dengan Hak Asasi Manusia (HAM) sebagai sebuah.

Dokumen penting yang dapat di katakan sedagai landasan konseb HAM dalam arti modern adalah Bill or Right yang menyerukan bahwa pemerintahan raja harus di arahkan bagi kepentingan perlindungan hak serta kebebasan individu. Dokumen ini lahir dari sebuah perebutan kekuasaan yang melibatkan perlemen Inggris dengan penguasa otoriter kaum monarki dinasti Stuart, yang lazim dikenal sebagai Glorius Revolusion.

Akhir hari perebutan kekuasaan ini adalah pemberian hak campur tangan parlemen dalam proses suksesi tahta kerajaan Inggris. Sekalipun secara sinis tahun $\mathrm{M}$ arxis menilai Glorius revolution lebih sebagai suaru revolusi tahun borjuis dari pada kebangkitan masyarakat (society). Namun bagaimanapun, peristiwa itu menandai munculnya issu HAM ketika rakyat (melalui parlemen) merasa berkepentingan untuk membebaskan diri dari kesewenangan penguasa monarki. Tuntutan reformasi layak di kumandangkan atau suatu keharusan, kebebasan berekspresi dan menyampaikan pendapat dimuka umum, demontrasi, mimbar bebas, dan pembangkanganpembangkangan politiklainya sebagai gerakan sosial untuk perubahan tatanan negara yang telah menyimpang dari cita- 
cita bangsa dan negara, sebagaimana diperintahkan olehuud 1945.

Gelombang reformasi telah menurunkan Soeharto sebagai presiden tanggal 21 Mei 1998, tetapi sangat disayangkan bahwa kegembiraan yang meluap-luap dari gerakan reformasi telah kehilangan format, karena orientasinya lebih banyak diarahkan pada figur dan bukan pada perubahan struktur dan kultural pada suatu rezim yang represif dan korup. Reformasi kehilangan arah, dampak yang timbul ialah masyarakat mengalami ketidakpastian, keresahan yang pada akhirnya timbul rasa putus asa dan frustasi, sehingga timbul kebebasan berekspresi dan menyampaikan pendapat dimuka umum yang bersifat liar, brutal, tak terkendali dan sikap-sikap anarkis, radikal lainya seperti timbul aksi pengrusakan, pembakaran, penjarahan dan perampokan.

\section{KAJIAN PUSTAKA}

Penelitian ini dilakukan dengan menggunakan pendekatan normatif, yaitu suatu pendekatan normatif, melalui penelitian studi pustaka artinya data yang ditelaah hanyalah data yang dipergunakan melalui studi pustaka saja atau hanya menggunakan data sekunder, baik dalam bentuk buku-buku literatur maupun peraturan perundang-undangan, terutama yang berkaitan dengan permasalahan yang dibahas.

\section{TUJUAN PENELITIAN}

Penelitian ini bertujuan untuk Mengetahui apakah kemerdekaan menyampaikan pendapat dimuka umum dapat dan dapat dikategorikan ke dalam tindak pidana. Dan mengetahui kriteria kemerdekaan menyampaikan pendapat dimuka umum dapat di kategorikan sebagai tindak pidana.

\section{METODE PENELITIAN}

1. Type Penelitian

Type penelitian hukum yang digunakan adalah Yuridis Normatif (hukum normatif). Metode peneitian hukum normatif adalah suatu prosedur penelitian ilmiah untuk menemukan kebenaran berdasarkan logika keilmuan hukum dari sisi normatifnya. Oleh karena itu penelitian hukum ini di fokuskan untuk mengkaji penelitian hukum tenteng kaidah-kaidah atau norma-norma dalam hukum positif yakni norma hukum yang terkait dengan Tinjauan Yuridis Kemerdekaan menyampaikan pendapat di muka umum menurut Undang-undang No. 9 tahun 1998

2. Pendekatan Masalah

Penelitian ini dilakukan dengan menggunakan pendekatan normatif, yaitu suatu pendekatan normatif, melalui penelitian studi pustaka artinya data yang ditelaah hanyalah data yang dipergunakan melalui studi pustaka saja atau hanya menggunakan data sekunder, baik dalam bentuk buku-buku literatur maupun peraturan perundang-undangan, terutama yang berkaitan dengan permasalahan yang dibahas.

3. Bahan Hukum

Bahan hukum yang digunakan adalah data sekunder ( secondary data ) karena penilitian yang dilakukan adalah penilitian normatif yang dalam hal ini menggunakan jenis data sekunder, yaitu data yang didapat dari buku-buku literatur melalui studi pustaka

4. Prosedur Pengumpulan Bahan Hukum

Dalam penelitian ini, data diperoleh dengan cara studi kepustakaan yaitu dilakukan dengan cara membaca dan mempelajari perundang-undangan yang berlaku sesuai dengan permasalah yang akan dibahas dalam penelitian ini.

5. Pengolahan dan Analisis Bahan Hukum 
Data yang mengarah pada kajiankajian yang bersifat teoritis dalam bentuk asas-asas, konsepsi-konsepsi, perundang-undangan, doktrin-doktrin hukum serta isi kaidah hukum dianalisis menggunakan metode kualitatif yang menghasilkan penelitian yang bersifat deskritif analisa yaitu yang bertujuan untuk menggambarkan secara tepat sifa-sifat suatu individu, keaadaan gejala atau keompok tertentu yang memanfaatkan cara berfikir deduktif untuk pada kesimpulan yang dapat dipergunakan sebagai dasar atau pedoman untuk membahas permasalahn yang ada selanjutnya Data yang diolah dengan menggunakan metode deduktif yaitu data yang diperoleh dan diolah dari hal-hal yang sifat khusus kemudian data yang diperoleh dari studi pustaka yang ada hubunganya dengan permasalahan, disusun secara sistematis, sehingga diperoleh hasil yang baik dan benar.

\section{HASIL PENELITIAN DAN PEMBAHASAN}

Kemerdekaan menyampaikan pendapat di muka umum adalah hak asasi manusia yang dijamin oleh Pasal 28 Undang-Undang Dasar 1945 yang berbunyi: "Kemerdekaan berserikat dan berkumpul, mengeluarkan pikiran dengan lisan dan tulisan dan sebagainya ditetapkan dengan Undang - Undang" dan Pasal 19 Deklarasi Universal Hak-hak Asasi Manusia yang berbunyi : "Setiap orang berhak atas kebebasan mempunyai pendapat dengan tidak mendapat gangguan dan untuk mencari, menerima dan menyampaikan keterangan dan pendapat dengan cara apapun juga dan dengan tidak memandang batas-batas" serta merupakan perwujudan demokrasi dalam tatanan kehidupan bermasyarakat, berbangsa dan bernegara. Namun agar dalam membangun demokrasi yang berkeadilan sosial dan menjamin hak asasi manusia diperlukan adanya suasana yang aman, tertib, dan damai, dan dilaksanakan secara bertanggung jawab sesuai dengan ketentuan peraturan perundang-undangan yang berlaku.

Negara demokrasi adalah negara yang menjunjung tinggi kedaulatan rakyat ,memberikan perlindungan hak-hak asasi warga negaranya. Diantara hak asasi tersebut adalah hak atau kebebasan menyampaikan pendapat, kebebasan pers, kebebasan berkumpul dan kebebasan berorganisasi, seperti yang termuat dalam piagam - piagam hak asasi manusia sedunia.

\section{PENUTUP}

Kemerdekaan menyampaikan pendapat dimuka umum; Demonstrasi, Unjuk rasa, mimbar bebas, rapat terbuka, pawai dan bentuk protes lainnya adalah hak asasi manusia yang dijamin oleh Piagam Hakhak asasi Dunia dan UUD1945, tetapi pelaksanaanya harus dilakukan secara bertanggung jawab dengan menjunjung tinggi nilai-nilai agama, kesusilaan dan tunduk pada ketentuan perundanganundangan yang berlaku, agar tidak mengganggu hak dan kebebasan orang lain serta kepentingan masyarakat. Berdasarkan unsur-unsur tindak pidana sebuah kemerdekaanmenyampaikan pendapat dimuka umum dapatdikategorikan sebagai tindak pidana, dengan melihat eksesyang ditimbulkan.

Kriteria kemerdekaan menyampaikan pendapat dimuka umum dapat dikategorikan tindak pidana bilamana memenuhi unsur-unsur tindak pidana yang meliputi :

1. Unsur Obyektif

2. Unsur Subyektif

Produk hukum yang menjadi faktor terhambatnya aspirasi massa-rakyat seperti UU Pemilu, UU Partai Politik dan golongan karya, UU Susunan kedudukan MPR, DPR, dan DPRD, UU organisasi kemasyarakatan, UU Referendum dan UU Pokok Pers serta produk hukum lainyang bermuatan mengekang kebebasan hak sipil 
dan politik harus diganti. Reformasi dalam semua bidang mutlak harus diganti. Reformasi dalam semua bidang mutlak harus dijalankan untuk memperbaiki sistim politik pemerintahan yang telah mengalami pembusukan. Kemerdekaanmenyampaikan pendapat dimuka umum dengan segala fenomenanya harus dilihat dan diselesaikan dengan arif dan bijaksana, hendaknya tidak dilihat sebagai ancaman yang perlu dirisaukan apalagi dituduh sebagai tindakan makar ataumerongrong idiologi negara yang melanggaraturan tentang kejahatan terhadap keamanan negara seperti dalam KUHP dan UU No.11 PNPS/1963 tentang tindak pidana subversi, sementara produk hukum ini sudah waktunya diganti dengan baru yang lebih mempunyai jiwa dan semangat reformasi.

DAFTAR PUSTAKA

Johhny ibrahim, Hukum Teori Dan Metode Penelitian Normatif (Banyumedia Publishing, Malang, 2006), hal. 25 Johhny ibrahim, Hukum Teori Dan Metode Penelitian Normatif (Banyumedia Publishing, Malang, 2006), hal. 25

R.Soesilo, Pokok-Pokok Hukum Pidana Peraturan Umum Dan DetikDetik Khusus, Politeia, Bogor, 1984

Phillip.G.Altbach, politik dan mahasiswa : Perspektif dan kecenderungan masa kini, PT. Graha Media, jakarta, 1998 